\title{
Physical Responding of the Urban Public Space to Citizens' Rights
}

\author{
Mohammad Yousefi \\ Master student of architecture, Islamic Azad University of Qazvin; Yousefi.m1365@yahoo.com
}

Robabeh Fardi

Master student of architecture, Islamic Azad University of Qazvin Science and Research Department; R.fardi86@yahoo.com

\section{Doi:10.5901/mjss.2016.v7n3s2p167}

\begin{abstract}
Urban public spaces are places for the presence of people and a platform for social interaction. Any person who is placed in these spaces is required to follow a set of rules and regulations and any space has provisions that specify the behavior in this space. But in addition to these provisions, any of the citizens who are placed in these spaces, have rights. Compliance with these rights has a direct impact on the welcoming of space, so that in case of observance these rights, more individuals participate in public spaces. In this article, we briefly talked about the public spaces and then we studied the rights that people have in public spaces and recognizing each of them. Finally, we expressed a sum of solutions to meet these rights in the physical environment.
\end{abstract}

Keywords: public space, rights of the people, people-oriented, urban space, social interaction.

\section{Introduction}

Today, urban public spaces have an important role in cities. The performance of public spaces is vast and various and in addition to meeting the needs of people, they are considered as a place for social and cultural exchanges of different people. The main purpose of this discussion is the creation of public space's socialization that makes the public space will be more pleasant and favorable in terms of visitors' point of view and will be a factor to encourage the presence and increasing the amount of communication with others. This space must meet the collective needs of humanity and with a proper design for him, offer different selections available to him.

Considering the appearance of the environment and human behavior similarity simply can expand the communication performance and the performance of environmental memory boost, to place an appropriate behavior and remind the people how to behave appropriately. Regarding the effect of environment on behavior, the environment is more than a place of residence, facility, or even stimulants. And not only they make us recall, but also they are also predictor and prescriber. In fact, they lead the answers, which means, they increase the possibility of certain responses by confining the scope of possible answers without being further defined. They order the response guidance. (Rapoport, 2013: 89)

\section{Urban Public Space}

A city is a cultural / physical series that is formed based on the needs, activities and its inhabitants' behaviors. Human are active based on their individual or group needs and offer their own behavioral patterns. The city and its spaces are platform or container for these same events, natural spaces and their properties depend heavily on the activities and behavior patterns of their users. Of course, this does not mean a one-sided relation. As the spaces on the one hand reflect the activities and behavior patterns of a community, on the other hand places have a strong influence on the activities and behaviors of their residents. (Pakzad, 2012: 76)

Downtown Public spaces provide opportunities for human interaction and leisure and enjoy from the environment. When these places of mass gathering display their own unique personality and add to the vitality and life of the streets in the downtown core can be act as solvent and strong incentives for private sector investment. (Paumier, 2012: 111)

Public space is normally defined as places that all citizens have access to it freely and legally. Public places, not only include the streets, squares and crossroads, but also they include indoor public spaces, such as libraries and 
community halls of municipalities. Public space is the space between private spaces - homes and workspaces, and often has special significance as free spaces of assembly and political participation, where marginalized segments of society can exercise their rights to their language. (Rafieian and Khodayi, 2010: 89)

It might be claimed that, the compatibility of space or physical with its current activities and behaviors is an important criterion for assessing the health, strength, and coordination of a society, in other words, a society that fails to provide a proper platform for its members' work and behaviors, cannot claim to be having cultural richness. Any behavior that is done by humans, primarily rely on the culture and the culture effects on architecture and urban spaces as a set of moral and material achievements of a society (including values, traditions, customs, knowledge and technology and ...), in fact, they are the physical manifestation of these minds. (Pakzad, 2012: 76)

\section{The Rights of People in Urban Space}

Control is the quality that increases the sense of belonging to space. From Francis' point of view, control of space includes "the ability of an individual or group to access, equip, impact, and obtain property and give meaning to a public space." Lynch believes that control is a very important quality in urban open spaces. He believes that control or lack of control can have important consequences that can affect the concerns, satisfied feeling and the proud. Lynch has identified five types of control: the presence, use and operation, ownership, compliance and submission.

Car et al by using the concepts of Lynch have recognized five aspects of citizens' rights in urban space. These aspects include the access, freedom of action, claim, change, ownership and transfer of rights. It is necessary to consider these qualities of citizenship and its physical manifestation in the urban space. (Abbaszadegan, 2006)

\subsection{Access}

Public spaces include a wide array of areas, from the old historical centers to developed suburban areas. If they are considered today as assets of urban renewal and new developments, our opinion is that the need and the success of public space is predetermined foremost by its ability to bring together, according to two essential and main qualities that the rest depends on it, which means the access and communication will be determined. (Tonnelat)

Space must be available to the public at any time. One meaning of access will be a sense that the public can act with the same freedom and discretion the same way they behave in any public space. (Whyte, 2014, 75)

Francis recognizes three types of access that include physical, social and intuitive access. Car et al also have added the symbolic access to this classification.

A) Physical access to urban space: Against accessing, barriers to access must also be considered. Such as, doors and gates, walls, fences, and changing the level (barriers to access for disabled). (Abbaszadegan, 2006)

Physical barriers will limit the use of the public space realm for community groups such as the disabled, the elderly, people who have paralyzed children, pregnant women, etc. Hall and Imrie observed that people with disabilities would experience the built environment in the form of a series of barriers. "Most buildings are not accessible with a wheelchair and a few of the buildings have the touchable distinction of color or a sufficient color contrast for certain people who are visually impaired. Color contrast makes these kinds of people to move easily in space. Some specific element design in spaces such as doors, handles, toilets has come in a standard form that will make the use of space for many people with mental and physical disabilities impossible. "

There are generally two types of disability in people: medical disability that often creates a specific medical condition. In this case, the person's disability factor is not relevant to his social context. Social disability refers to the type of disability that comes through obstacles that resulting from the imposition of community or the environment, to an individual and result in his non-compliance with the environment. In this case, people will have disabilities and the environment makes them disable. (Carmona, 2013, 259)

If all members of society equally have the right to participate in public life - safe and comfortable - first children, the elderly and persons with disabilities should be considered. (Pakzad, 2013, 153)

B) Social access: all classes and social strata should be able to use the space. Banning the use of space for layers or class of society is considered a kind of social exclusion and will reduce the utilization of space. (Abbaszadegan, 2006)

It is very important if we can provide the power of choosing and diversity in accessing to activities, resources, information and different places, for all segments of our society. Urban environments must be available for all - regardless of age, ability, background and income - and could create selectivity in accessing to activities, buildings and different resources for everyone. (Tibbaldz, 2009, 85)

C) Visual access: The possibility of seeing the space is presented as visual access. Many researchers, including 
Wiedermann who has observed the lack of visual access to the Space is a barrier to the use of space, in a way that visual barriers have strong correlation with the fear of crime and in such a case, citizens feel insecurity. On the other hand, the visual access should not be an obstacle to creating a cozy environment that is part of the need. Too much clarity will eliminate the exploring and wondering of space quality. (Abbaszadegan, 2006)

If we want to see and understand an event, it should happen in front of the observer and almost at the same level; this is the fact that is reflected in the design of all the spaces that viewers attend - theaters, cinemas, and auditoriums. In theaters, the balcony tickets have a lower cost because the events cannot be seen properly and no one wants to sit in the lower level of the floor. (Gehl, 2009, 57)

Anyone can observe others at a distance of half to one kilometer, which this observing depends on factors such as the foreground and light, whether the considering people are moving or not. At a distance of about 100 meters, bodies that could be seen from a distance are recognizable. This area could be called the social vision. (Ibid., 59)

D) Symbolic access: Sings in space shows that the presence of whom is pleasant or not in the space. For example, a space guard may prevent the entering of certain individuals or groups in the space or some kind of users or Performance (Type shops, playgrounds for different ages, etc.) encourages the entering of certain people to more space. Using physical elements in the design of space, will remind to individuals the threshold for entry into some territories. (Abbaszadegan, 2006)

\subsection{Freedom of action}

Freedom is the right to use a space and activities in it. The space users, consciously or unconsciously recognize that urban spaces are spaces that should be used jointly with other individuals and groups. Therefore, they should behave so as not to disturb others.

Few people are disagreeing with Sir Colin Buchanan's opinion that has offered 25 years ago: "Conditions that an individual can walk freely in an urban environment and looks around, are considered as the most important sign of its civilization quality ". However, after nearly three decades, there are still many obstacles to the freedom of pedestrians, mostly are originated from the traffic management practices and how to build and place these buildings. (Tibbaldz, 2009, 75).

Some social groups in space will limit other groups' activity. Such as groups of youth that limit the women's activities in space, or addicts and offenders in parks and forest parks around the city that practically limit the use of this type of spaces. According to the advice of Car and his colleagues, diverse activities encourage in a space can provide freedom of action strategies in groups. On the other hand, the detailed and proper design of a space is very effective in the freedom of action in different groups, as individuals and groups each can have a part of the space and assign a specific territory to benefit from it and do not disturb each other. (Abbaszadegan, 2006)

\subsection{Territory claim}

Many theorists have witnessed a decline in the public space territory, meaning that a part is related to the reduction in the availability of public space and collective life meaning and the public space. Ellin says many social and civic functions that occur in public spaces have already been transferred to private spaces. Such as recreational activities, absorbing the information and the consumption that increasingly can be done at home via television and the Internet. Activities that have been taken place publicly and collectively before, now are available individually and privately and the use of spaces is under the influence of specific changes and improvements such as increasing mobility of people by using the car and the Internet. Social relations in public spaces are affected by the conflict between the demand for social space and the responding need to move with the car. In fact, the cars facilitate the public spaces control. (Carmona, 2013, 221)

Loukaitou-Sideris and Banerjee say the public life include relatively open and universal social background and, in return, there is a private life term that are the intimate, familiar, with shelter, controlled by the individual and shareable with the family. The realm of public space has physical and social dimensions. The Physical realm of public space is spaces that are owned in the form of private or public, will ease and provide the public life flow and the social interaction. Activities and events that are going on in these spaces and contexts are called social-cultural realm of the public spaces. (Ibid., 218)

In order to gain the interest on a space, should give the space users an opportunity and allowance to claim a part of space. People claim parts of public space to gain territory and privacy in certain circumstances. According to Proshansky's opinion, a territorial claim will allow the beneficiaries of space to increase the range of their choice and maximize their freedom to choose and in space. 
In Micro-spaces of urban, areas that are formed by transposed walls, porches, order of green space, the eradication of urban furniture and moveable urban furniture, can be effective for citizens in claiming a part of the space by one, two or a group of users.

Claiming a part of space as your territory and your group can cause problems, including the exclusion of others from the alleged space. For example, the accumulation of homogeneous groups in parts of space can make the use of space by people who are not members of the group, unpleasant. (Abbaszadgan, 2006)

In general, the public territory is a relatively fragile and unstable mechanism to monitor the border between yourself and others; it is more dependent on conventions, norms, and social customs than to regulations that are self-imposed. That is why, in the restaurants, they put tables so that people do not disturb each other, and they put the chairs of the bus away from each other, so people do not have much physical contact with each other and public telephone booths often have a door or acoustic material that prevents others listening to their talk. (Altman, 2012, 147)

\subsection{Change}

Change is the transformation ability of space. In these circumstances, the needs of users in the space can be responded. Lynch offered the change similar to the mitigation concept. Change in space may be temporary or permanent. In the temporary changes, the people using the space will bring their required objects such as furniture, kiosks, game net, small flower, or any other means to the space, will make the needed changes, and will put the things out of the space after doing the activity. In fact, people bring change elements (liberal elements) into space with them. Permanent changes must be made in some events. In this case, the space should be adjustable and applicable to the needs. (Abbaszadegan, 2006)

\subsection{Ownership and Assignment}

The right of ownership is the highest degree of control right, which is higher than the right of access, activity, claims and change. Two types of ownership can be distinguished, traditional ownership and social ownership. Traditional ownership is based on legal ownership. According to legal ownership, the society will grant the rights of the owner to control all aspects of space.

The second type of ownership is social ownership. Francis explains how this type of ownership (residents' ownership of a housing complex) can better meet the needs of residents and on the other hand, how it can prevent additional costs and environmental destruction and increase the compatible power of the environment with the needs. (Abbaszadegan, 2006).

If a person attributes to a neighborhood or particular space, the responsibility for that space will power and because he sees himself related to that space, he finds his honor in making the space better and helps to improve the situation. In people-oriented spaces, people know the space as their own because their presence plays a special role for others and the space is different with or without their presence. In addition, a high potential is for participation in-group activities or even in nature of the environment. (Bakhtiar nasrabadi and others, 2012)

\section{Physical Considerations of Citizens' Rights}

With explanations of urban public spaces, the need to respond the people's needs and respect their rights was well defined in these spaces. What can be said is that urban public space that cannot do the operation is practically an unsuccessful space.

Items that are suggested as the rights of people in urban areas involve five categories: access, freedom of action, claim of territory, change, ownership, and assignment that each of these requires a series of physical factors that can make a responsive space.

In various parts of the following considerations can help us to achieve a responsive space to the rights of peoples:

1. Access

- Removing barriers to access

- Use ramps

- Common space

- The level of spaces

- Having a scale and a proper distance

- No restrictions into space 


\section{- Public space}

2. The Freedom of Action

- encouraging the diverse activities in a space

- Careful and proper design for not bothering each other

3. The claim of territory

- Use of transposed walls

- Creating the porches

- Green space order

- How eradicate the urban furniture

- Moveable Urban furniture

4. Change

- The transformation of space

- The possibility of adding objects into space by users

5. Ownership and Assignment

- Participate in group activities and the nature of the environment

\section{Conclusion}

Mentioned overview about the public spaces of the city's physical response to citizens' rights, in a general conclusion, can be stated in Table 1. Observing these items in our design, create a space that with a view to citizenship rights will welcome more by the majority and will become a successful space in the city.

Table 1: Goals and Strategies of people's rights in urban areas (writer)

\begin{tabular}{|c|c|c|c|}
\hline \multicolumn{2}{|c|}{ Rights of people } & \multirow{2}{*}{$\begin{array}{l}\text { Strategy } \\
\text { Access for all (children, the elderly, the disabled } \\
\text { and the blind) }\end{array}$} & \multirow{2}{*}{$\begin{array}{l}\text { Design Considerations } \\
\text { Remove barriers to access } \\
\text { the use of ramps }\end{array}$} \\
\hline Access & Physical & & \\
\hline & Social & Access all classes and social strata & Common space \\
\hline & Visual & Visibility of space and activities & $\begin{array}{l}\text { The level of spaces } \\
\text { Having a proper scale and distance }\end{array}$ \\
\hline & Symbolic & Space for everyone & $\begin{array}{l}\text { No limitations into space } \\
\text { Public space }\end{array}$ \\
\hline \multicolumn{2}{|c|}{ Freedom of action } & The use of space and activities for all & $\begin{array}{l}\text { Encouraging diverse activities in a space } \\
\text { Careful and adequate design of space for not bothering } \\
\text { each other }\end{array}$ \\
\hline \multicolumn{2}{|c|}{ Claim of territory } & $\begin{array}{l}\text { To gain territory and Privacy } \\
\text { Claim part of the space }\end{array}$ & $\begin{array}{l}\text { The use of transposed walls } \\
\text { Creating porches } \\
\text { Green space Order } \\
\text { How to eradicate the urban furniture } \\
\text { Moveable Urban furniture }\end{array}$ \\
\hline \multicolumn{2}{|l|}{ Change } & Meet the different needs of users & $\begin{array}{l}\text { The ability to transform the space } \\
\text { The possibility to add objects into space by users }\end{array}$ \\
\hline \multicolumn{2}{|c|}{ Ownership and Assignment } & $\begin{array}{l}\text { The space belonging to all people } \\
\text { Sense of responsibility for the space }\end{array}$ & $\begin{array}{l}\text { Participation in group activities and the nature of the } \\
\text { environment }\end{array}$ \\
\hline
\end{tabular}

\section{References}

Rapoport, Amos, (2013), "the meaning of the built environment", translation of Farah Habib, second edition, Tehran: Information and Communication Technology Organization of Tehran Municipality

Pakzad, Jahanshah, (2013), "Theoretical Foundations and urban design process", Fifth Edition, Tehran: Shahidi publication

Paumier, Sai, (2013), "creation of a vibrant city center", translation of Mustafa Behzadfar, Amir Shakiba Manesh; second edition, Tehran: Iran University of Science and Technology

Rafieian, Mojtaba; Khodayi, Zahra, (2009), "Citizens and public spaces of the city", first edition, Tehran: Science creating expand office Abbaszadegan, Mostafa, (2006), "Social- psychological aspects of urban spaces", International Journal of Engineering Science, Volume 16

Tonnelat, Stephane, The Sociology of urban public spaces , Associate Researcher CNRS, CRH-LAVUE, Research Center, Paris Whyte, William, (2014), "the social life of small urban spaces", translation M.asoud Asadi Mahal Chaly, first edition, Tehran: Arman 
Shahr publication

Carmona, Matthew, [and others], (2013), "public spaces urban spaces the demnsions of urban design" , translators Fariba Gharayi, [and others], second edition, Tehran: Tehran Art University Press

Tibbaldz, Francis, (2009), "MAKING PEOPLE-FRIENDL TOWN", translated by Mohammad Ahmadinejad, the second edition, Isfahan, Khak Publication

Gehl, Jan, (2009), "Life between buildings:using public space", translation Shima Shasti, first printing, Tehran, University Jihad Organization Publications

Altman, Lrwin, (2012), "The Environment and social behavior", translated by Ali Namazian, second edition, Tehran: University of Shahid Beheshti

Bakhtiar Nasr Abadi, Ameneh; Bakhtiar Nasr Abadi, Hassanali; Bakhtiar Nasr Abadi, Ahmad, (2012), "An Analysis of the people-oriented urban space and its relation with citizenship behavior", Applied Sociology, the twenty-second year, consecutive numbers (43), the third number 